EPiC Series in Biological Sciences
Volume 1, 2021, Pages 54-60

\title{
Stomatal Number and Size of Dicotyledon Plants
}

\author{
Dia Widi Hastika ${ }^{1}$ and Entin Daningsih ${ }^{1 *}$ \\ ${ }^{1}$ Universitas Tanjungpura, Pontianak, Indonesia \\ entin.daningsihefkip.untan.ac.id
}

\begin{abstract}
The stomatal number and size influence transpiration, a process of water loss in the plant that cools its environmental temperature. Some dicotyledon plants function as shading plants, especially in the urban area. However stomatal number and size of some plants are not known. This study aimed to know the stomatal number and size in dicotyledon shading plants. The method used factorial completely randomized design (CRD) with the main factors of six dicotyledon plants and plant part of the lowest branch. Whilst the combinations were between the two. The stomatal number and size were sampled using a replica method from these treatments and observed under 10x10 and 10x40 magnification, subsequently. The stomatal number were counted used hand counter and size were measured using a calibrated micrometer. Data were analyzed using SAS with a model of factorial CRD. Both main factors were significant whereas the combinations were not. for stomatal number and size. The highest stomatal number and the largest stomatal size occurred in Syzygium oleana $\mathrm{R} . \mathrm{Br}$ and Aerva sanguinolenta $\mathrm{Bl}$, subsequently. The Syszygium has the highest number but the smallest size of stomata whereas Aerva sanguinolenta $\mathrm{Bl}$ has the other around. The more the leaves developed the smaller number but the bigger size of stomata.
\end{abstract}

\section{Introduction}

The stomatal number and stomatal size play a role in transpiration. In plants, water in the form of vapor gets lost to the atmosphere through a process called transpiration via openings, or stomata in the leaf surfaces (Meinzer et al., 1997). Transpiration has a cooling effect and drives the needed force to take up water and nutrients from the soil solution and pump them through the plant body (Adrew et al., 2004). The bigger size of stomata would increase the water loss resulting in cooling temperature at Dononea viscosa (Hill et al., 2014). Reductions in stomatal density constrain gas exchange and transpiration to conserve water use efficiency. However, in some cases, the stomatal size would enlarge 
in response to the change of environment resulting in maximum and minimum gas exchange. These plastic modulations of the number and size of stomata allow plants to adjust their stomatal pore area in response to the surrounding environment (Bertolino et al., 2019). In conditions of drought stress, the stomata function will close, as an effort to restrain the transpiration rate. The compound that plays a role in opening and closing the stomata is abscisic acid, a compound that acts as a signal of drought stress so that the stomata closes immediately. Some types of plants adapt to drought stress by reducing the size of the stomata and the number of stomata (Juairiah, 2014).

Increased stomata opening occurs in the range of 09.00-10.00 AM. At 09.00-10.00 AM, the number of stomata and the diameter of the opening of the stomata show the highest number. However, the decline began at 11.00 AM A very sharp decline occurred at noon. At 2.00 PM there was an increase again and experienced a decline again in the afternoon around 3.00-5.00 PM (Fatonah et al., 2013).

According to Sutrian (2011), the leaves of the Dicotyledons plant contain many stomata, in each $\mathrm{cm}^{2}$ of the plant leaves there are around 1000 to 100,000 stomata. Based on the research of Haryanti (2010), it was found that the number of stomata in dicotyledonous and monocotyledonous plants varied in each type of plant. Based on the research of Istiqomah (2016) which examined the number of stomata found the highest number of stomata was possessed by dicotyledons plants is Syzygium oleana R.Br. (161) and the lowest number of stomata was possessed by monocotyledons plants is Pterocarpus indicus Willd (377). Both Syzygium Sp. and Pterocarpus Sp. are ornamental plants. Furthermore study of the analysis of stomata size was carried out by Vivin (2017) stating that the size of the monocotyledons stomata had the longest and largest stomata size than the size of the stomata in dicotyledonous plants. This is in line with the results of Tambaru (2013), explaining that the size of the stomata is inversely proportional to the number of stomata on the leaves of plants. If the size of the stomata is small then the number of stomata found in the leaves is large whereas if the stomata are large, the number of stomata on the leaves is small. Each plant has a different size of stomata, which is influenced by internal factors such as its genetic traits and external factors, namely the environment in which the plants are located (Juairiah, 2014).

The stomata number and size are therefore needed to know to find out how the plants transpire due to stomatal number and size. Nevertheless, no information regarding how fast the transpiration rate due to stomatal number and size. On the other hand, many dicotyledon plants function as shading and therefore related to stomatal number and size. Information about stomatal number and size for dicotyledon plants that function as shading plants are very few. Camargo and Morenco (2011) stated that the stomatal density of each plant's species depends mainly on genetic factors rather than the environment. In shading plants that are used in Pontianak mostly dicotyledon plants. The stomatal number and size of those species are not known. This research purposed to know the stomatal number and size of six dicotyledon plants used as shading plants. By obtaining the information of the stomatal number and size from those plants will help to choose the suitable plants becoming shading plants.

\section{Materials and Methods}

The tools were pots, scopes, scissors, glass objects, microscope, micrometers, hand counters, handphone cameras, laptops, and logbooks. The materials were clear nail polish, sticky tape, labels, and six dicotyledon plants, namely Codiaeum variegatum Bl., Excoecaria cochinchinensis Lour., Aerva sanguinolenta Bl., Tabernaemontana corymbosa, Syzygium oleana R.Br., and Bougainvillea spectabillis Willd.

Plants replanted into pots with the same planting media as before. The selected plants were six species of dicotyledonous plants, namely Codiaeum variegatum B1., Excoecaria cochinchinensis Lour., Aerva sanguinolenta Bl., Tabernaemontana corymbosa, Syzygium oleana R.Br., Bougainvillea spectabillis Willd. The criteria for the selected plants were relatively small plants, no waxy leaf, no 
pubescence. The process of making slides stomata used the replica method that was carried out directly on the leaves that are still intact on each plant. This was done to avoid stomata close. The leaves were taken from the lowest branch of the plant. The leaf has taken from the top, middle, and bottom of this branch for making the slide. The slides were made for the upper and lower surface of the leaf. The sampling time is from $09.00 \mathrm{am}-10.00 \mathrm{am}$, sampling time refers to the results of research conducted by Fatonah, et al. (2013) which states that the highest increase in the number of stomata and porous opening diameter occurs in plant samples taken at 9:00 am to 10:00 am. Determination of the number of stomata refers to the research of Haryanti (2010) with modifications at a 10x10 micrometer magnification. The criteria for the number of stomata according to Haryanti (2010) are as follows: few (1-50), quite a lot (51-100), many (101 -200), very much (201>300), and infinite (>300).

After micrometer calibration, the length and width of the stomata were measured. The measurement of stomata length and width in this study refers to the research conducted by Vivin (2017). Measuring the length and width of the stomata can be determined by multiplying the number of long and widescale shadows with the value of the micrometer ocular. The calculation of stomata length and width was done using a calibrated micrometer on the ocular lens and replacement objective micrometer with a sample slide. The stomata area calculation refers to Vivin (2017). The following formula of the stomata area was: stomata area $=\pi \times$ a x b (Eberly, 2008) where $\pi=3.14, \mathrm{a}=$ the stomata length radius and $\mathrm{b}=$ stomata width radius.

The data were analyzed using SAS with the model of factorial CRD. If the results showed a significant effect, then proceeded with the Least Square Different test (LSD) at alfa 0.05. In addition, a correlation test between the number of stomata and stomata size was conducted to see whether there was a relationship between the number and the size of the stomata. The correlations were categorized into the range of very low (0.00-0.199), low (0.20-0.399), medium $(0.40-0,599)$, strong $(0.60-0,799)$, and very strong $(0,80-1,000)$ (Widiyanto, 2014).

\section{Results and Discussion}

The observation of stomata replica slides of six dicotyledon plants showed that stomata could be found on the upper and lower surface of the leaves at Aerva sanguinolenta $\mathrm{Bl}$. and Tabernaemontana corymbosa while Codiaeum variegatum BI., Excoecaria cochinchinensis Lour., Syzygium oleana R.Br., and Bougainvillea spectabillis Willd could be found only on the bottom surface of the leaf (abaxial). Hidayat (1995) and Campbell (2008) explains that stomata can be found on both sides of the leaf or only on one side, or more often on the lower surface of the leaf. This is a mechanism of plant adaptation to the environment to reduce water loss through the stomata. According to Afa and Sudarsono (2014), this adaptation may be influenced by the physiological activity of plants to avoid stomata against direct exposure to sunlight so that more stomata were found on the lower surface of the leaves. The results showed six dicotyledon plants had different stomatal numbers with the highest number was Syzigium oleana (927) and the lowest stomata number was Aerva sanguinolenta Bl. (314) (Table 1). All six species dicotyledons plants were included in the infinite category. With this infinite category, these six dicotyledons shading plants potentially had high transpiration. According to Hill et al. (2014), the increase of the stomatal number would accelerate transpiration. This results as an infinite category so all six dicotyledons plants can function as shading plants. However, the stomatal number of these six dicotyledon plants was different significantly (Table 1) although they were in the same stomatal category.

The results of Factorial-CRD analysis showed plant species and plant parts had affected significantly on stomatal numbers (Table 1) but the combination did not. LSD test was conducted for plant species and plant parts. 


\begin{tabular}{|c|c|c|}
\hline Variables & $\begin{array}{l}\text { Mean of stomatal } \\
\text { number }\end{array}$ & $\underset{\ddagger}{\text { Significance }}$ \\
\hline Plant & & * \\
\hline Syzygium oleana $\mathrm{R} \cdot \mathrm{Br}$ & $927^{\mathrm{a}}$ & \\
\hline Codiaeum variegatum BI & $495^{\mathrm{b}}$ & \\
\hline Excoecaria cochinchinensis Lour & $484^{\mathrm{b}}$ & \\
\hline Tabernaemontana corymbosa & $422^{\mathrm{c}}$ & \\
\hline Bougainvillea spectabillis Willd & $372^{\mathrm{d}}$ & \\
\hline Aerva sanguinolenta $\mathrm{Bl}$ & $314^{\mathrm{e}}$ & \\
\hline Plant Parts & & $*$ \\
\hline Top & $527^{\mathrm{a}}$ & \\
\hline Middle & $513^{\mathrm{a}}$ & \\
\hline Bottom & $468^{\mathrm{b}}$ & \\
\hline Combinations of Plant Species and Plant Parts & & ns \\
\hline Codiaeum variegatum BI $*$ Top & 517 & \\
\hline Codiaeum variegatum $\mathrm{BI} *$ Middle & 495 & \\
\hline Codiaeum variegatum $\mathrm{BI} *$ Bottom & 474 & \\
\hline Excoecaria cochinchinensis Lour* Top & 524 & \\
\hline Excoecaria cochinchinensis Lour* Middle & 490 & \\
\hline Excoecaria cochinchinensis Lour* Bottom & 438 & \\
\hline Aerva sanguinolenta $\mathrm{Bl} *$ Top & 345 & \\
\hline Aerva sanguinolenta $\mathrm{Bl} *$ Middle & 325 & \\
\hline Aerva sanguinolenta $\mathrm{Bl} *$ Bottom & 272 & \\
\hline Tabernaemontana corymbose $*$ Top & 429 & \\
\hline Tabernaemontana corymbose $*$ Middle & 421 & \\
\hline Tabernaemontana corymbose $*$ Bottom & 416 & \\
\hline Syzygium oleana $\mathrm{R} . \mathrm{Br} *$ Top & 975 & \\
\hline Syzygium oleana $\mathrm{R} . \mathrm{Br} *$ Middle & 974 & \\
\hline Syzygium oleana $\mathrm{R} . \mathrm{Br} *$ Bottom & 833 & \\
\hline Bougainvillea spectabillis Willd * Top & 373 & \\
\hline Bougainvillea spectabillis Willd * Middle & 372 & \\
\hline Bougainvillea spectabillis Willd $*$ Bottom & 372 & \\
\hline
\end{tabular}

Table 1: Analysis of the variance on the stomatal number using factorial CRD.

${ }^{¥} \mathrm{~ns}=$ non-significant, $*=$ significant at $\alpha=0.05, * *=$ significant at $\alpha=0.01, * * *=$ significant at $\alpha=0.001$. $=0.05$. different letters behind the mean within the same column were significantly different when tested with LSD at $\alpha=0.05$.

The Least Square Difference (LSD) test (Table 1) showed the highest stomatal number was Syzygium oleana $\mathrm{R} . \mathrm{Br}$ (927) significantly different from others and followed by Codiaeum variegatum BI. (495), Excoecaria cochinchinensis Lour (484) that were similar to each other but different from the rest. The following plant species namely Tabernaemontana corymbose (422), Bougainvillea spectabillis Willd. (372), and Aerva sanguinolenta Bl. (314) had fewer stomatal numbers and different from each other significantly. Aygun (2014) explained that the stomatal number could vary among plant species according to growth conditions and ecological factors that might produce some differences in the anatomy of the stomata and the number of stomata. Meidner and Mansfield (1968) stated that there were more stomata in leaves exposed to sunlight than leaves in shading area, and more stomata on plant leave that grow on dry soils and had low humidity compared to plants that grew on the ground moist and high humidity. This was supported by Hariyanti (2010) who suggested that the same species and planted in different shade affect the stomata number were decreased with reducing light intensity. This was related to the efforts of plants to adapt to their environment and the function of the stomata as the 
place for the transpiration process to take place. Besides, Hidayat (1995) explained that the number of stomata varied in the leaves and areas of the leaves of the same plant.

LSD test showed the leaves from the top (527) and the middle part (513) of the plant was similar to each other but different significantly from those bottom parts (468) of the plant (Table 1). Stomata on the top part looked tight and dense so that the stomatal number became numerous. Al's et al. (2003) stated that the stomata index was more on young leaves than adult leaves and the lowest was on developed leaves. In developed leaves (bottom part), epidermal cells had grown in term of size so the stomata area in the same field of view became larger but the stomatal number became fewer. This was supported by Yudha et al. (2013) who stated that stomata density in the leaves was influenced by leaf growth. The stomatal density in angsana (Pterocarpus indicus) leaves at the age of 15 days was quite high and became stable when entering the age of 20 days.

Then the stomatal size calculation was carried out which consisted of measuring the length and width of the stomata and calculating the area of the stomata. Calculation of the stomata area was obtained from the measured length and width measurements using a formula by Eberly (2008). The analysis of variance about stomatal size showed the main factors both plant species and plant parts of the plant influenced significantly stomatal size. However, the stomatal size was not affected by the combinations of main factors (Table 2).

\begin{tabular}{|c|c|c|}
\hline Variable & $\begin{array}{c}\text { Mean of the stomatal size } \\
(\mu \mathrm{m})\end{array}$ & Significance ${ }^{¥}$ \\
\hline Plant & & * \\
\hline Aerva sanguinolenta $\mathrm{BI}$ & $708.95^{\mathrm{a}}$ & \\
\hline Bougainvillea spectabillis Willd & $508.29^{\mathrm{b}}$ & \\
\hline Variable & $\begin{array}{l}\text { Mean of the stomatal size } \\
(\mu \mathrm{m})\end{array}$ & Significance ${ }^{\ddagger}$ \\
\hline Codiaeum variegatum $\mathrm{B} 1$ & $485.72^{\mathrm{b}}$ & \\
\hline Tabernaemontana corymbosa & $373.86^{\mathrm{c}}$ & \\
\hline Excoecaria cochinchinensis Lour & $331.99^{\mathrm{c}}$ & \\
\hline Syzygium oleana $\mathrm{R} . \mathrm{Br}$ & $230.59^{d}$ & \\
\hline Part & & * \\
\hline Top & $414.82^{b}$ & \\
\hline Middle & $425.29^{\mathrm{b}}$ & \\
\hline Bottom & $479.59^{\mathrm{a}}$ & \\
\hline Combination Plant and Part & & ns \\
\hline Codiaeum variegatum $\mathrm{B} 1 *$ Top & 520.06 & \\
\hline Codiaeum variegatum $\mathrm{Bl} *$ Middle & 404.27 & \\
\hline Codiaeum variegatum $\mathrm{Bl} *$ Bottom & 532.82 & \\
\hline Excoecaria cochinchinensis Lour* Top & 325.77 & \\
\hline Excoecaria cochinchinensis Lour * Middle & 330.68 & \\
\hline Excoecaria cochinchinensis Lour $*$ Bottom & 339.51 & \\
\hline Aerva sanguinolenta $\mathrm{BI} *$ Top & 621.62 & \\
\hline Aerva sanguinolenta $\mathrm{BI} *$ Middle & 716.80 & \\
\hline Aerva sanguinolenta BI * Bottom & 788.43 & \\
\hline Tabernaemontana corymbosa $*$ Top & 327.73 & \\
\hline Tabernaemontana corymbosa $*$ Middle & 360.11 & \\
\hline Tabernaemontana corymbosa $*$ Bottom & 433.71 & \\
\hline Syzygium oleana $\mathrm{R} . \mathrm{Br} *$ Top & 213.91 & \\
\hline Syzygium oleana $\mathrm{R} . \mathrm{Br} *$ Middle & 216.85 & \\
\hline Syzygium oleana $\mathrm{R} . \mathrm{Br} *$ Bottom & 261.01 & \\
\hline
\end{tabular}


Bougainvillea spectabillis Willd * Top Bougainvillea spectabillis Willd * Middle

Bougainvillea spectabillis Willd * Bottom
479.83

523.00

522.024

Table 2: Analysis of the variance in the stomata area using factorial CRD.

${ }^{\ddagger} \mathrm{ns}=$ non-significant, $*=$ significant at $\alpha=0.05, * *=$ significant at $\alpha=0.01$, *** = significant at $\alpha=0.001 .=$ 0.05 . different letters behind the mean within the same column were significantly different when tested with LSD at $\alpha=0.05$.

The plant species and plant part influenced significantly on the stomatal size in terms of area. However, the combinations of plant species and plant parts did not affect the stomatal area (table 2). Aerva sanguinolenta BI. was significantly the largest stomata area $(708.95 \mu \mathrm{m})$ compared to others. Bougainvillea spectabillis Willd $(508.29 \mu \mathrm{m})$ and Codiaeum variegatum $\mathrm{Bl}(485,72 \mu \mathrm{m})$ were similar in the stomata area but smaller significantly than that of Aerva sanguinolenta BI. Then Tabernaemontana corymbose $(373.86 \mu \mathrm{m})$ and Excoecaria cochinchinensis Lour $(331.99 \mu \mathrm{m})$ were smaller stomatal area than previous plant species. The two of them had similar stomata area. Lastly, Syzygium oleana $\operatorname{R.Br}(230.59 \mu \mathrm{m})$ had the smallest stomatal area significantly compared to others. The stomatal area of the leaves from the bottom $(479.59 \mu \mathrm{m})$ part of the plant was larger than those of the middle and the top parts of the leaves. However, the stomatal number of the leaves from the middle $(425.59 \mu \mathrm{m})$ and the top $(414.82 \mu \mathrm{m})$ were not different significantly to each other. Each plant had a different stomatal size that was influenced by internal factors such as genetic traits and external factors such as the environment in which the plant was located (Juairiah, 2014). According to Haryanti (2010), the size of stomata was influenced by the presence of light absorbed by chloroplast which conducts photosynthesis, guard cell turgidity, rising temperature, and energy that can affect the stomata opening. This widening of the porous stomata was closely related to the transpiration of these plants in adapting to their environment. Stomata reduce its wide to reduce water transpiration. On the contrary, the stomata open widely in the shaded area. Therefore, the stomata area could change depending on physiological and environmental conditions. The change occurs due to the guard cells' ability flexibility. No combination of plant species and plant parts has different effects significantly. Different from other research conducting in monocotyledons plant the combination was not significant. In monocotyledons plant, the bottom, middle, and top parts of the plant were not the same as in dicotyledons plant. In dicotyledons plant, the sample of the leaves was taken from the lowest branch in the plant that might be having similar sunlight absorption and affected the combination.

The stomatal number was negatively correlated $(r=-0.65)$ with the stomatal area. This showed that the higher the stomatal number, the smaller of stomatal area. Tambaru (2013) explained that the size of stomata was inversely proportional to the number of stomata on the leaves of the plant. If the size of stomata was small, the number of stomata found on the leaves was high whereas if the stomata was large, the number of stomata on the leaves was few. Doheny et al. (2012) also revealed similar things that in general there was a negative correlation between stomatal size and stomatal density. Likewise, Franks et al (2009) stated the relationship that occurred between stomatal density and size was inversely proportional. As the stomatal density increased, the stomatal size was smaller. From this research, both stomatal size and stomatal numbers were affected by plant species and plant parts. The highest stomatal number belonged to Syzygium oleana $\mathrm{R}$.Br but it has the smallest stomatal size compared to other plants. How this stomatal numbers that negatively correlated with stomatal size for transpiration need further research. The achievement to obtain this information will help to choose plants that function as shading plants optimally. 


\section{References}

Andrew JG, Michael AC, and Ignacio RI. (2004). Effect of Vertical Resolution on Predictions of Transpiration in Water-limited Ecosystems. Advances in Water Res. 27: 467-480

Al SD, Suryani, and Rahmawati. (2003). Tanggapan Stomata dan Laju Transpirasi Daun Vaccinium (BI) Miq. Menurut Tingkat Perkembangan Daun dan Jarak Terhadap Sumber Emisi Gas Belerang Kawah Sikidang Dataran Tinggi Dieng. In Bahasa. Seminar Hasil Penelitian MIPA, FMIPA UNY.

Afa LO and Sudarsono WA. (2014). Pengaruh Naungan Terhadap Pertumbuhan dan Hasil Tanaman Kolesom (Talinum triangule (jacq.) Willd.). In Bahasa. AGRIPLUS. 24(02): 144-151.

Aygun A. (2014). Determination of Stomatal Density and Distribution on Leaves of Turkish Hazelnut (Corylus avellana L.) Cultivars. Journal Of Agricultural Sciences. 20: 454-459.

Camargo MAB and Morenco RA. (2011). Density, size, and distribution of stomata in 35 rainforest tree species in Central Amazonia. Acta Amazonia. 41(2): 205-212

Doheny AT, Hunt L, Franks PJ, Beerling DJ, and Gray JE. (2012) Genetic manipulation of stomatal density influences stomatal size, plant growth, and tolerance to restricted water supply across a growth carbon dioxide gradient. Philos Trans $R$ Soc Lond B Biol Sci. 367 (1588): 547-555. http://rstb. royalsocietypublishing.org accessed online November 7, 2018).

Eberly D. (2008). The Area of Intersecting Ellipses. United States of America. Geometric Tools Redmond WA 98052.

Fatonah S, Asih D, Mulyanti D, and Iriani D. (2013). Penentuan Waktu Pembukaan Stomata pada Gulma Melastoma malabathricum L. di Perkebunan Gambir Kampar, Riau. In Bahasa. Biospesies. 6 (2): 15-22.

Franks PJ, Drake PL, and Beerling D. (2009). Plasticity in maximum stomatal conductance constrained by negative correlation between stomatal size and density: analysis using Eucalyptus globulus. Plant Cell Environ. 32: 1737-1748.

Haryanti S. (2010). Pengaruh Naungan yang Berbeda Terhadap Jumlah Stomata dan Ukuran Porus Stomata Daun Zephyranthes rosea Lindl. In Bahasa. Buletin Anatomi dan Fisiologi. XVIII(1).

Hill EK, Guerin RG, Hill SR, and Watling RJ. (2014). Temperature influences stomatal density and maximum potential water loss through stomata of Dodonaea viscosa subsp. angustissima along a latitude gradient in southern Australia. Australian Journal of Botany. 62(8): 657-665.

Hidayat EB. (1995). Anatomi Tumbuhan Berbiji. In Bahasa. Bandung: Institut Teknologi Bandung.

Istiqomah G. (2016). Pembuatan Mulitimedia Interaktif Anatomi Daun Kelas XI SMA berdasarkan Analisis Jumlah Stomata dan Kadar Klorofil Tumbuhan di Jalan Tanjungpura dan Imam Bonjol. Skripsi. In Bahasa. Pontianak: FKIP Universitas Tanjungpura.

Juariah L. (2014). Studi Karakter Stomata Beberapa Jenis Tanaman Revegetasi di Lahan Pasca Pengembangan Timah di Bangka. In Bahasa. Widyariset. 17 (2): 213-218.

Meidner H and Mansfield TA. (1968). Physiology of Stomata. New Delhi: McGraw Hill Book Company.

Meinzer FC, Hinckley TM, Ceulemans R (1997). Apparent Responses of Stomata to Transpiration and Humidity in a Hybrid poplar Canopy. Plant Cell Environ. 20 (10): 1301-1308.

Tambaru E, Latunra AI, and Suhadiyah S. (2013). Peranan Morfologi dan Tipe Stomata dalam Mengabsorpsi Karbondioksida pada Pohon Hutan Kota UNHAS. In Bahasa. Simposium National Kimia Bahan Alam. XII:12-17.

Vivin D. (2017). Kelayakan Powerpoint Interaktif Organ Tumbuhan Kelas XI SMA Berdasarkan Analisis Ukuran dan Tipe Stomata di Kota Pontianak. In Bahasa. Skripsi. Pontianak: Universitas Tanjungpura.

Yudha GP, Noli ZA, and Idris M. 2013. Pertumbuhan Daun Angsana (Pterocarpus indicus Willd) dan Akumulasi Logam Timbal (Pb). In Bahasa. Jurnal Biologi Universitas Andalas (J. Bio. UA.) 2 (2): 83-99. 